\title{
ОСОБЛИВОСТІ ВИКОРИСТАННЯ КАРАГІНАНІВ ЯК ХАРЧОВИХ ДОБАВОК
}

\section{Особливості використання карагінанів як харчових добавок}

О. М. Копаниця ${ }^{1}$, А. А. Гудима ${ }^{2}$ О. П. Мялюк ${ }^{1}$, Н. В. Ліснянська ${ }^{3}$, І. М. Кліщ ${ }^{2}$

КзВО «Рівненська медична академія» Рівненської обласної ради ${ }^{1}$

Тернопільський національний медичний університет імені І. Я. Горбачевського МОЗ України ${ }^{2}$

Буковинський державний медичний університет мОЗ України ${ }^{3}$

Резюме. Серед харчових добавок полісахариди добре відомі як функціональні добавки, які мають високу молекулярну масу, добре розчиняються у воді й використовують їх для поліпшення текстури кінцевої продукції. В останні десятиріччя карагінани стали одними з найпопулярніших гідроколоїдів у харчовій промисловості.

Мета дослідження - проаналізувати літературні джерела щодо особливостей використання карагінанів як харчових добавок.

Матеріали і методи. У дослідженні опрацьовано наукові публікації за останнє десятиліття, які доступні у мережі «Internet», ключовими словами були «карагінан», «харчові добавки», «Е407».

Результати. Широке використання каппа-карагінану пов'язане з його здатністю до підвищення в'язкості водних розчинів та гелеутворення, застосовують у харчовій, легкій та аграрній промисловостях. А також при виробництві консерв, м'ясних і молочних продуктів. Карагінанам притаманні властивості імуноад'ювантів: вони здатні надавати як імуностимулювальний, так і імуносупресорний ефекти. Їх вплив на імунну систему носить дозозалежний характер. У високих концентраціях ці полісахариди не мають імуносупресорної дії, імовірно, унаслідок цитотоксичності відносно супресорних клітин. Водночас карагінан при низьких дозах стимулює активацію супресорних макрофрагів і пришвидшує їх дозрівання. Деяка суперечливість даних про фрармакологічну дію цих полісахаридів може бути зумовлена некоректним порівнянням результатів, отриманих у різних експериментальних умовах, на різних структурних типах карагінанів. При цьому дуже важливим є спосіб введення полісахариду і його доза.

Висновки. Широке використання карагінанів як природного, так і синтетичного походжень надихає науковців глибше досліджувати механізм їх дії на рівні цілого організму.
Features of the use of carrageenans as nutritional supplements

O. M. Kopanytsia ${ }^{1}$, A. A. Gudyma ${ }^{2}$, O. P. Mialiuk ${ }^{1}$, N. V. Lisnianska ${ }^{3}$, I. M. Klishch ${ }^{2}$

${ }^{1}$ Rivne Medical Academy

${ }^{2}$ I. Horbachevsky Ternopil National Medical University

${ }^{3}$ Bukovinian State Medical University

e-mail: kopanycya651@ukr.net

Summary. Among the nutritional supplements, polysaccharides are well known as functional additives that have a high molecular weight, are well soluble in water and used to improve the texture of the final product. In recent decades, carrageenan became one of the most popular hydrocolloids in the food industry.

The aim of the study - to analyze literary sources about the peculiarities of the use of carrageenans as nutritional supplements.

Materials and Methods. Scientific publications for the last decade that are available in the Internet network were studied; keywords were "carrageenan", "food additives", "E407".

Results. The widespread use of kappa-carrageenan is associated with its ability to increase the viscosity of aqueous solutions and gel formation, so it is widely used in food, light and agricultural industries. Carrageenan is widely used in the production of cans, meat and dairy products. Carrageenan is inherent in the properties of immunoaders: they are capable of granting both immunostimulating and immunosuppressive effects. The influence of carrageenans on the immune system have dose-dependent character. In high concentrations, these polysaccharides have no immunosuppressive action, probably due to cytotoxicity in relation to suppressor cells. At the same time, carrageenan at low doses stimulates the activation of suppressor macrophages and accelerates their maturation. Some contradictional data on the pharmacological effect of these polysaccharides may be due to incorrect comparison of the results obtained in various experimental conditions, on various structural types of carrageenans. In this case, it is very important to introduce polysaccharide and its dose.

Conclusions. The widespread use of carrageenans as natural and synthetic origin causes scientists to a deeper study of the mechanism of their action at the level of a whole organism. 


\section{ВСТУП}

Розвиток харчової індустрії, сучасний рівень наукових досліджень у галузях теоретичної та прикладної хімії, біохімії, біотехнології, фрізіології, гігієни харчування та нутриціології; динамічне зростання обсягів виробництва та асортименту продуктів харчування, а також інтенсивна інтеграція України в світову спільноту зумовлюють широке використання харчових добавок у технології харчових продуктів $[1,2]$. Серед них добре відомі як фрункціональні добавки полісахариди, що мають високу молекулярну масу, добре розчиняються у воді й використовуються для поліпшення текстури кінцевої продукції [3-5]. В останні десятиріччя карагінани стали одними з найпопулярніших гідроколоїдів у харчовій промисловості [6].

Метою дослідження було проаналізувати літературні джерела щодо особливостей використання карагінанів як харчових добавок.

\section{МАТЕРІАЛИ І МЕТОДИ}

У дослідженні опрацьовано наукові публікації за останнє десятиліття, які доступні у мережі «Internet», ключовими словами були «карагінан», «харчові добавки», «Е407».

\section{РЕЗУЛЬТАТИ Й ОБГОВОРЕННЯ}

Широке використання каппа-карагінану пов'язане з його здатністю до підвищення в'язкості водних розчинів та гелеутворення, застосовують у харчовій, легкій та аграрній промисловостях. А також при виробництві консерв, м'ясних і молочних продуктів. Експертний комітет з харчових добавок ФАО/ВООЗ встановив допустиму добову дозу карагінану - до 75 мг на 1 кг маси тіла. Дослідники вказали, що для солодких страв забезпечення необхідної міцності структури гелів можливе за умови використання каппа-карагінану при концентрації 0,6 \%, а для гелів для солоних страв - каппа-карагінану при концентрації 0,8 \% [7].

Ця харчова добавка (Е407) об'єднує сімейство полісахаридів (відоме також під назвою ірландський мох), що містяться в червоних морських водоростях Chondrus Crispis, Eucheuma Species, Gigartina Species тощо. За хімічною природою карагінан близький до агароїдів і являє собою нерозгалужені сульфатовані гетероглікани, молекули яких побудовані із залишків похідних D-галактопіранози зі строгим чергуванням $\alpha-(1,3)-$ і $\beta-(1,4)-3 в$ 'язків між ними, тобто 3 повторюваних дисахаридних ланок, що включають залишки $\beta$-D-галактопіранози і

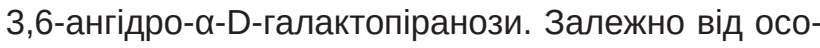
бливостей будови дисахаридних повторюваних ланок розрізняють три основних типи карагінанів, для позначення яких використовують літери грецького алфравіту [8, 9].

У природі полісахариди можна знайти майже в усіх живих організмах, у тому числі в тканинах насіння, стебел і листя лікарських рослин, рідинах організму тварин, клітинних стінках і позаклітинній рідині бактерій, дріжджів і грибів [10]. Із розвитком молекулярної біології наукове співтовариство дійшло висновку, що полісахариди на рівні з білками і полінуклеотидами є надзвичайно важливими біомакромолекулами, які відіграють незамінну роль у зростанні й розвитку живих організмів [11]. Природні полісахариди рідко мають регулярну структуру. Найчастіше це суміш різних типів карагінанів, які утворюють полімерний ланцюг складної гібридної структури. В процесі багатоступінчастого біосинтезу полісахаридів у клітинній стінці водорості може утворюватися комбінація різних ідеальних карабіозних ланок, розподілених уздовж полімерного ланцюга, що і призводить до утворення гібридних структур. У так званих каппа- і йота-карагінанах можуть міститися не тільки каппа- і йота-карабіозні ланки, але і їх біосинтетичні попередники мю- $(\mu$, D6SG4S) або ню- (v, D2S6S-G4S) відповідно [12, 13]. Регулярні полісахариди, полімерний ланцюг яких побудований з повторюваних дисахаридних ланок одного типу, отримали власні назви, і, згідно 3 номенклатурою, умовно діляться на гелюючі й негелюючі типи. Біосинтез карагінану залежить як від екзогенних, що визначаються умовами існування водоростей, так і ендогенних фракторів, пов'язаних із їх орізіологією, зокрема зі стадією розвитку макрофрітів $[14,15]$. Останній фрактор особливо важливий, так як червоні водорості мають складний життєвий цикл, що включає чергування вегетативного, статевого і безстатевого розмноження. Перші роботи із встановлення структури карагінану проводилися в основному на зразках полісахаридів, виділених із суміші різних фрорм водорості, що значно ускладнювало інтерпретацію отриманих результатів і призводило до отримання неоднозначних даних. Спостереження за фразою життєвого циклу водорості дозволили виявити нові структури карагінанів і оцінити вплив їх на біосинтез полісахариду. Так, ретельний аналіз виділених полісахаридів показав, що карпоспорофріти Gigartina skottsbergii й Gymnogongrus torulosus продукують гелеутворювальні k/ı-карагінани, цистокарпи Iridaea undulosa -k/t- і частково $\mu / v$-карагінани водночас як в тетраспорофітах останньої водорості синтезуються $\lambda$-карагінани, гелеутворювальні при високій концентрації KCl $[16,17]$. Разом з тим, у тетраспорофрітах Gigartina atropurpurea продукується комплекс по- 
лісахаридів, полімерний ланцюг яких містить суміш не тільки негелеутворювальних $\lambda$-, $\theta$ - і $\rho$-карагінанів, але також несульфатованих 3,6-ангідрогалактозних ланок [18]. Гелеутворювальні полісахариди, представлені ı/ $\alpha$-карагінанами, утворюються цистокарпами водорості Stenogramme interrupta, тоді як тетраспорофріт цього макрофріту містить негелеутворювальні $\theta$ - і $\lambda$-карагінани $[19,20]$. Однак представники сімейств Soleriaceae, Hуoneaceae i Furcellariaceae синтезують тільки k- і $\theta$-карагінани, незалежно від фрази розвитку водорості [21].

Карагінани, зазвичай, утворюють дуже в'язкі водні розчини, що пов'язано зі структурою їх лінійних макромолекул і поліелектролітною природою. Взаємне відштовхування негативно заряджених сульфатних груп уздовж полімерного ланцюга $€$ причиною того, що молекула стає сильно протяжною, водночас як її гідрофрільна частина знаходиться в гідратній оболонці. Обидва ці фрактори призводять до підвищення в'язкості розчину. Як і для більшості природних полісахаридів, для карагінанів характерна полідисперсність 3 молекулярної маси (MМ). Більшість карагінанів має ММ від 100 до 500 кДа. Зазвичай вони формують розчини з в'язкістю від 25 до 500 мПа, за винятком $\lambda$-карагінану, який може утворювати високов'язкі розчини до 20000 мПа [22]. Карагінани, розчини яких мають в'язкість менше 100 мПа, мають властивості, близькі до ньютонівських рідин. Ступінь відхилення від ньютонівської поведінки збільшується 3 концентрацією і ММ полісахариду [23]. В'язкість водних розчинів карагінанів залежить від типу і ММ полісахариду, присутності певних іонів і температури [24]. Солі знижують в'язкість розчинів карагінанів, зменшуючи електростатичне відштовхування сульфатних груп. В'язкість розчинів карагінанів залежить від концентрації полімеру, конорормації його макромолекули в розчині й ММ.

Технологічний процес отримання карагінанів оснований на їх екстракції гарячою водою з подальшим виділенням із розчину. В промисловості використовують два способи виділення: через гелеутворення в середовищі 3 хлоридом калію - для виділення гелеутворювальних карагінанів; осадженням із спирту - при виділенні суміші всіх типів [25, 26]. У ряді речовин, здатних відновлювати фрункціональну активність імунокомпетентних клітин, особливе місце відводиться природним полісахаридам, які можуть не тільки модулювати різні властивості імунної системи, але і володіють здатністю до абсорбції радіонуклідів, важких металів і бактерій, нормалізації ліпідного обміну, активації секретуючої і моторної фрункцій кишечника [27]. Характерною особливістю карагінанів є їх здатність утворювати комплекси з іонами деяких металів, при цьому катіони металів взаємодіють із сульфратними групами сусідніх ділянок молекул карагінану з утворенням міжмолекулярних «мостиків», за рахунок яких відбувається формування і стабілізація структури карагінанового гелю [28]. Здатність карагінанів до утворення комплексів із металами залежить перш за все від індивідуальних особливостей їх структури. Реакція імунної системи на пероральне введення полісахаридів не носить загального характеру. Імунотропну дію деяких рослинних полісахаридів можна віднести до френомену харчової толерантності, а ряду інших - до явища посилення імунної відповіді [29, 30]. Серед різнобічності біологічної активності карагінанів на сьогодні найбільший інтерес привертають противиразкова, антикоагуляційна, протипухлинна і противірусна [31, 32]. Біологічні властивості карагінанів знаходяться в тісному зв'язку з їх фрізико-хімічними властивостями і структурою, яка відрізняється великою різноманітністю (на сьогодні описано близько 20 типів різних видів) і блоковою будовою полімерного ланцюга, що визначається родової приналежністю водорості й умовами її зростання [33]. Найяскравішими представниками є три типи карагінанів: каппа, йота та лямбда.

Такі полісахариди полійонної природи як карагінани здатні до багатоточкової взаємодії із поверхнею імунокомпетентних клітин, що може забезпечувати модуляцію різних ланок імунної системи. В експериментах in vivo показано, що карагінан впливає на синтез імуноцитами прозапальних цитокінів, таких, як інтерлейкін-1, інтерлейкін-6 та орактора некрозу пухлин і $є$ індукторами інтерорерону - важливого неспецифічного фактора захисту організму від інфекції [34]. Здатність полісахаридів пригнічувати ріст вірусу простого герпесу і багатьох інших вірусів відома вже близько 40 років, але довгий час не викликала особливого інтересу дослідників, оскільки вважалася неспецифічною, і механізм її залишався нез'ясованим. Однак після того як було встановлено інгібуючу дію гепарину та інших сульфатованих полісахаридів на реплікацію ВІЛ, ці полімери привернули увагу як потенційні агенти для лікування і профрілактики захворювань, викликаних даним вірусом. На сьогодні відомо, що сульфатовані полісахариди мають широкий спектр антивірусної активності щодо великого числа вірусів 3 оболонкою, включаючи так звані умовно патогенні, такі, як вірус простого герпесу, цитомегаловірус та інші, що виникають в організмі при ослабленні фрункції імунної системи [35, 36]. Вчені, досліджуючи взаємозв'язок структурних особливостей карагінанів і їх антивірусної дії, вважають, що в проявленні інгібуючої дії щодо багатьох вірусів, визначальну роль відіграє присутність $\alpha$-зв'язаної D-галактози і сульфатних груп у 2 і 6 положеннях залишку галактози в полісахаридах, при цьому часткова циклізація, в результаті якої утворюється 3,6-ангідро-Dгалактоза, призводить до суттєвого зниження
Вісник медичних і біологічних досліджень Bulletin of Medical and Biological Research
$2(8), 2021$ 
активності [37]. В основі механізму дії карагінанів на віруси лежить здатність сульфатованих полісахаридів блокувати шляхи проникнення віріона в клітину-господаря, можливо, завдяки антиадгезивним властивостям або за рахунок структурної спорідненості 3 деякими компонентами вірусної частинки [38, 39], саме наявність негативно заряджених груп у молекулах полісахаридів, яка зумовлює схожість з будовою вірусних глікопротеїнів, сприяє блокуванню специфрічної взаємодії вірусів із клітинними рецепторами CD4 і лежить в основі їх інгібуючої дії щодо багатьох ретровірусів [40, 41].

Карагінанам притаманні також властивості імуноад'ювантів: вони здатні надавати як імуностимулювальний, так і імуносупресорний ефекти [42]. Вплив карагінанів на імунну систему носить дозозалежний характер. У високих концентраціях ці полісахариди не мають імуносупресорної дії, імовірно, унаслідок цитотоксичності щодо супресорних клітин. Водночас карагінан при низьких дозах стимулює активацію супресорних макрофрагів і пришвидшує їх дозрівання [43]. Деяка суперечливість даних про фрармакологічну дію цих полісахаридів може бути зумовлена некоректним порівнянням результатів, отриманих у різних експериментальних умовах, на різних структурних типах карагінанів. При цьому дуже важливим $€$ спосіб введення полісахариду і його доза.

Завдяки своїм фрізико-хімічним властивостям карагінан має досить широке застосування. Близько 70 \% виробленого в світі карагінану використовується в харчовій промисловості: при виробництві молочних (шоколадне молоко, щербети, домашній сир, сирні пасти, дитяче харчування), м'ясних і рибних продуктів (консерви, оболонки ковбас, желейні покриття), приправ, безалкогольних напоїв, хлібобулочних (хлібне тісто, фрруктові кекси, цукрові глазурі) й кондитерських виробів [44]. Їх застосовують як гелеутворювачі й стабілізатори емульсій у системах, заснованих на молоці й воді, а також для поліпшення властивостей інших гелів. Це можливо завдяки

\section{СПИСОК ЛІТЕРАТУРИ}

1. Stryamets N. From economic survival to recreation: contemporary uses of wild food and medicine in rural Sweden, Ukraine and NW Russia / N. Stryamets // Journal of Ethnobiology and Ethnomedicine. - 2015. - Vol. 11. URL : https://ethnobiomed.biomedcentral.com/articles/10.1186/ s13002-015-0036-0.

2. Kopanytsia O. M. Carrageenan induces cell death in rats blood / O. M. Kopanytsia, M. I. Marushchak, I. Y. Krynytska // International Journal of Medicine and Medical Research. - 2018. - Vol. 4, Iss. 1. - P. 67-70.

3. Costa M. Use of edible films and coatings in cheese preservation: Opportunities and challenges / M. Costa // Food Research International. - 2018. - Vol. 107. - P. 84-92.

4. The influence of carrageenan on markers of здатності карагінанів утворювати комплекси 3 іншими гідроколоїдами $[45,46]$. Карагінани мають порівняно високу температуру розрідження, тому їх використовують при приготуванні фрруктових кондитерських виробів. Модифріковані карагінани перешкоджають окисненню жирів і $є$ хорошими антиокиснювачами. У вигляді коагулянту їх використовують у м'ясних консервах, фрруктових гелях і желе. Відомо їх використання в їстівній глазурі для зберігання продуктів [47]. Друге місце за споживанням добавок після харчової індустрії займає косметична промисловість. Їх застосовують при виготовленні лосьйонів, кремів, шампунів не так через хороші реологічні властивості, скільки через так званий залишковий ефрект: карагінан пом'якшує шкіру. Сприятливо впливає на кератин волосся, доданий в шампунь або фріксатор, робить волосся більш слухняним, імовірно, за рахунок зв'язування вологи і зняття статичного електричного заряду [48]. Відомо застосування карагінану в текстильній промисловості. В біотехнологічному виробництві його використовують для іммобілізації клітин і як замінник бактеріологічного агару [49]. Він відносяться до розчинних харчових волокон. Доведено, що харчові волокна відіграють значну роль у регулюванні гомеостазу та дозволяють досить ефективно регулювати метаболічні й функціональні порушення. Карагінан здатний викликати регенерацію шкіри, стимулювати зростання сполучної тканини і застосовують його для створення гелевої і плівкової основи для різних ранозагоювальних пов'язок $[45,46,48]$. Однак наявні літературні дані про фрізіологічну активність карагінанів наведені в основному для комерційних зразків та в більшості своїй не враховують структурні особливості цих сульфратованих полісахаридів.

\section{ВИсновки}

Широке використання карагінанів як природного, так і синтетичного походжень надихає науковців глибше досліджувати механізми їх дії на рівні цілого організму.

endogenous intoxication in rats / M. Marushchak, I. Krynytska, O. Kopanytsia [et al.] // National Journal of Physiology, Pharmacy and Pharmacology. - 2018. - Vol. 8 (3). - P. 412-419.

5. Копаниця О. М. Метаболічні процеси у стінці тонкої кишки, серці й печінці при експериментальному застосуванні карагінану / О. М. Копаниця, М. І. Марущак, А. А. Щербатий // Медична та клінічна хімія. - 2017. T. 19, № 3 (72).- C. 108-113.

6. Mahmood W. A. K. Effects of reaction temperature on the synthesis and thermal properties of carrageenan ester / W. A. K. Mahmood, M. M. R. Khan, T. C. Yee // Journal of Physical Science. - 2014. - Vol. 25, No. 1. - P. 123-138.

7. Мартинов С. В. Застосування каппа-карагінану у 
складі харчових продуктів. / С. В. Мартинов, Т. І. Маренкова // Матеріали наук. конф. студентів Сумського НАУ. - Суми, 2015. - T. III. - С. 182.

8. Булдаков А. С. Пищевые добавки. Справочник / А. С. Булдаков. - М. : ДеЛиПринт, 2001. - 435 с.

9. Пищевая химия. - изд. 2-е, перераб. и испр. I А. П. Нечаев и др. ; под ред. А. П. Нечаева. - Спб. : ГИОРД, 2003. - $640 \mathrm{c}$.

10. Singh V. Use of microwave irradiation in the grafting modification of the polysaccharides - A review / V. Singh, P. Kumar, R. Sanghi // Progress in Polymer Science. - 2012. - Vol. 37. - P. 340-364.

11. Cosgrove D. J. Growth of the plant cell wall / D. J. Cosgrove // Nature Reviews Molecular Cell Biology. 2005. - Vol. 6. - No. 11. - P. 850-861.

12. D'Ayala G. G. Marine derived polysaccha-rides for biomedical applications: Chemical modification approaches / G. G. D'Ayala, M. Malinconico, P. Laurienzo // Molecules. 2008. - Vol. 13. - P. 2069-2106.

13. Laurienzo P. Marine polysaccharides in pharmaceutical applications: Anoverview. / P. Laurienzo // Marine Drugs. - 2010. - Vol. 8. - P. 2435-2465.

14. Carrageenans: Biological properties, chemical modifications and structural analysis / V. L. Campo, D. F. Kawano, D. B. da Silva, I. Carvalho // Carbohydrate Polymers. - 2009. - Vol. 77. - P. 167-180.

15. Carrageenan: A natural seaweed polysaccharide and its applications / V. D. Prajapati, P. M. Maheriya, G. K. Jani, H. K. Solanki // Carbohydr. Polym. 2014. - Vol. 105. P. 97-112.

16. Estevez J. M. Carrageenans biosynthesized by carposporophytes of red seaweeds Gigartina skottsbergii (Gigartinaceae) and Gymnogongrus torulosus (Phyllophoraceae) / J. M. Estevez, M. Ciancia, A. S. Cerezo // J. Phycol. - 2002. - Vol. 38. - P. 344-358.

17. Nayouf M. Étude rhéologique et structurale de la qualité texturante du sys-tème amidon/kappa-carraghénane en relation avec le traitement thermomécanique (Thèse de Doctorat) / M. Nayouf Nantes. - France: École Nationale des Ingénieurs des Tech-niques des Industries Agricoles et Alimentaires. 2003. -198 p.

18. Falshaw R. Structure and performance of commercial kappa-2 carrageenan extracts. Pt III. Structure analysis and performance in two dairy applications of extracts from the New Zealand red seaweed / R. Falshaw, H. J. Bixler, K. Johndro // Food Hydrocolloids. - 2003. - Vol. 17. - P. 129-139.

19. Cáceres P. J. Carrageenans from chilean samples of Stenogramme interrupta (Phyllophoraceae): structural analysis and biological activity / P. J. Cáceres // Phytochemistry. - 2000. - Vol. 53. - P. 81-86.

20. Leibbrandt A. lota-carrageenan is a potent inhibitor of influenza avirus infection / A. Leibbrandt // PLoS ONE. 2010. - Vol. 5. - P. 1-12.

21. De SF-Tischer P. C. Chemical structure and antiviral activity of carrageenans from Meristiella gelidium against herpes simplex and dengue virus / P. C. De SF-Tischer // Carbohydrate Polymers. - 2006. - Vol. 63, No. 4. - P. 459-465.

22. Wijesekara I. Biological activities and potentialhealth benefits of sulfated polysaccharides derived from marine algae / I. Wijesekara, R. Pangestuti, S. K. Kim // Carbohydrate Polymers. - 2011. - Vol. 84, No. 1. - P. 14-21.

23. Yang L. Q. Chemical structural and chain conformational characterization of some bioactive polysaccharides isolated from natural sources / L. Q. Yang, L. M. Zhang // Carbohydrate Polymers. - 2009. - Vol. 76, No. 3. - P. 349-361.

24. Yuguchi Y. Structural characteristics ofcarrageenan gels: Various types of counter ions. / Y. Yuguchi, H. Urakawa, K. Kajiwara // Food Hydrocolloids. - 2003. - Vol. 17. P. 481-485.

25. Патюков С. Д. Вплив харчових волокон різних типів на якісні показники м'ясних консервів / С. Д. Патюков, І. А. Окунєва, М. І. Златова // Наукові праці Одеської національної академії харчових технологій. - 2009. - Вип. 36 (2). - C. 94-97.

26. Stoma M. Food allergies in rural areas / M. Stoma // Adv. Dermatol. Allergol. - 2016. - Vol. XXXIII, No. 4. - P. 281-285.

27. Webber $\mathrm{V}$. Optimization of extraction of carrageenan / V. Webber // Ciênc Tecnol. Aliment. - 2012. - Vol. 32, No. 4. P. 812-818.

28. Dilute iota- and kappa-Carrageenan solutions with high viscosities in high salinity brines. / S. Iglauer, Y. Wu, P. Shuler [et al.] // Journal of Petroleum Science and Engineering. - 2011. - Vol. 75. - P. 304-311.

29. Naude P. J. Potassium humate inhibits carrageenaninduced paw oedema and a graft-versus-host reaction in rats / P. J. Naude, A. D. Cromarty, C. E. Van Rensburg // Inflammopharmacology. - 2010. - Vol. 18. - P. 33-39.

30. Anti-inflammatory activity of ethanolic extract of Physalis alkekengi / J. Estakhr, N. Sanchooli, S. H. Najafi, N. Javdan // Research Journal of Pharmaceutical, Biological and Chemical Sciences. - 2011. - Vol. 2. - P. 421-425.

31. Benard C. Degraded carrageenan causing colitis in rats induces TNF secretion and ICAM-1 upregulation in monocytes through NF-kappaB activation. / C. Benard // PLoS ONE. - 2010. - Vol. 5, No. 1. - P. e8666.

32. Carlucci M. J. Protective effect of a natural carrageenan on genital herpes simplex virus infectionin mice / M. J. Carlucci // Antiviral Research. - 2004. - Vol. 64. P. 137-141.

33. Falshaw R. Structural analysis of carrageenans from the red alga, Callophyllis hombroniana Mont. K (Kallymeniaceae, Rhodophyta) / R. Falshaw, R. H. Furneaux, D. E. Stevenson // Carbohydr. Research. - 2005. - Vol. 340, No. 6. - P. 1149-1158.

34. De Jesus R. M. F. Marine polysaccharides from algae with potential biomedical applications / R. M. F. De Jesus, A. M. de Morais, R. M. de Morais // Marine Drugs. - 2015. -Vol. 13, No. 5. - P. 2967-3028.

35. Haijin M. A K-carrageenan derived oligosaccharide prepared by enzymatic degradation containing anti-tumor activity / M. Haijin, J. Xiadu, G. J. Huashi // Appl. Phicol. 2003. - Vol. 15, No. 4. - P. 297-303.

36. Cunha L. Sulfated seaweed polysaccharides as multifunctional materials in drug delivery applications / L. Cunha, A. Grenha // Marine Drugs. - 2016. - Vol. 14, No. 3. - P. 42.

37. Chattopadhyay K. Galactan sulfate of Grateloupia indica: Isolation, structural features and antiviral activity / K. Chattopadhyay // Phytochem. - 2007. - Vol. 68, No. 10. - P. 1428-1435.

38. Necas J. Carrageenan: A review / J. Necas, L. Bartosikova // Vet. Med. - 2013. - Vol. 58, No. 4. P. 187-205.

39. Carlucci M. J. Antiherpetic activity and mode of action of natural carrageenans of diverse structural types / M. J. Carlucci // Antiviral Res. -1999. - Vol. 43, No. 2. - P. 93-102.

\section{$2(8), 2021$}


40. Schaeffer D. J. Anti-HIV activity of extracts and compounds from algae and cyanobacteria / D. J. Schaeffer, V. S. Krylov // Ecotoxicology and Environmental Safety. 2000. - Vol. 45, No. 3. - P. 208-227.

41. Ghosh T. Focus on antivirally active sulfated polysaccharides: From structure-activity analysis to clinical evaluation / T. Ghosh // Glycobiology. - 2009. - Vol. 19, No. 1. - P. 2-15.

42. Kara S. Monovalent and divalent cation effects on phase transitions of k-carrageenan / S. Kara, E. Arda, O. Pekcan // Journal of Bioactive and Compatible Polymers. 2007. - Vol. 22, No. 1. - P. 42-61.

43. Bondu S. Carrageenan from Solieria chordalis (Gigartinales): Structural analysis and immunological activities of the low molecular weight fractions / S. Bondu // Carbohydr. Polym. - 2010. - Vol. 81, No. 2. - P. 448-450.

44. Османьян Р. Г. Перспективы использования каррагинанов в кондитерском производстве (для производства желейных конфеет с фрункциональными свойствами) / Р. Г. Османьян // Пищевая и перерабатывающая промышленность. Ресреративный журнал. 2008. № 2.- C. 432 .

\section{REFERENCES}

1. Stryamets N. From economic survival to recreation: contemporary uses of wild food and medicine in rural Sweden, Ukraine and NW Russia. Journal of Ethnobiology and Ethnomedicine. 2015;11. Available from: https:// ethnobiomed.biomedcentral.com/articles/10.1186/s13002015-0036-0.

2. Kopanytsia OM, Marushchak MI, Krynytska IY. Carrageenan induces cell death in rats blood. International Journal of Medicine and Medical Research. 2018;4;1: 67-70.

3. Costa M. Use of edible films and coatings in cheese preservation: Opportunities and challenges. Food Research International. 2018;107: 84-92.

4. Marushchak M, Krynytska I, Kopanytsia O, Tupol L, Savchenko I, Mazur L. The influence of carrageenan on markers of endogenous intoxication in rats. National Journal of Physiology, Pharmacy and Pharmacology. 2018;8(3): 412-9.

5. Kopanytsia OM, Marushchak MI, Shcherbatyi A.A. [Metabolic processes in the small intestine, heart disease in the experimental stagnation of Karaginan]. Med ta klin khim. 2017;72;19: 108-13. Ukrainian.

6. Mahmood WAK., Khan MMR., Yee TC. Effects of reaction temperature on the synthesis and thermal properties of carrageenan ester. Journal of Physical Science. 2014;25: 123-38.

7. Martynov SV, Marenkova TI. [Storing kappacarrageenan at the warehouses of food products]. Materials of Sciences. conf. students of Sumy NAU. 2015; 182. Ukrainian.

8. Buldakov AS. Food additives. Directory. [Пищевые добавки. Справочник] Moscow: DeLiPrint; 2001. Russian.

9. Nechaev A P. Food chemistry. [Пищевая химия. изд. 2-е, перераб. и испр.] St.-Petersburg: GIORD; 2003. Russian.

10. Singh V, Kumar P, Sanghi R. Use of microwave irradiation in the grafting modification of the polysaccharides - A review. Progress in Polymer Science. 2012;37: 340-64.
45. Michon C. Structure evolution of carrageenan/ milk gels: effect of shearing, carrageenan concentration and nu fraction on rheological behavior / C. Michon // Food Hydrocolloids. - 2005. - Vol. 19, No. 3. - P. 541-547.

46. Thaiudom S. Effect of k-carrageenan on milk protein polysaccharide mixtures / S. Thaiudom, H. D. Goff // Int. Dairy J. - 2003. - Vol. 13, No. 9. - P. 763-771.

47. Carrageenan as an alternative coating for papaya (Carica papaya L. cv. Eksotika) / H. M. Hamzah, A. Osman, C. P. Tan, F. Mohamad Ghazali // Postharvest Biology and Technology. - 2013. - Vol. 75. - P. 142-146.

48. Yermak I. M. Carrageenans-sulfated polysaccharides from red seaweeds as matrices for the inclusion of echinochrome / I. M. Yermak // Mar. Drugs. - 2017. Vol. 15 (337). URL : pdfs.semanticscholar.org/a362/ ea5f48 8b1351b7073ace53d9327a34916d33.pdf

49. Structural characteristics of carrageenan gels: Temperature and concentrations dependence. / Y. Yuguchi, T. T. Thu Thuy, H. Urakawa, K. Kajiwara // Food Hydrocolloids. - 2002. - Vol. 16, No. 6. - P. 515-522.

11. Cosgrove DJ. Growth of the plant cell wall. Nature reviews molecular cell biology. 2005;6;11; 850-61.

12. D'Ayala G G., Malinconico M, Laurienzo P. Marine derived polysaccha-rides for biomedical applications: Chemical modification approaches. Molecules. 2008;13: 2069-2106.

13. Laurienzo P. Marine polysaccharides in pharmaceutical applications: Anoverview. Marine Drugs. 2010;8: 2435-65

14. Campo VL, Kawano DF, Silva DB, Carvalho I. Carrageenans: Biological properties, chemical modifications and structural analysis. CarbohydratePolymers. 2009;77: 167-80.

15. Prajapati VD, Maheriya PM, Jani GK, Solanki HK. Carrageenan: A natural seaweed polysaccharide and its applications. Carbohydr Polym. 2014;105: 97-112.

16. Estevez JM, Ciancia M, Cerezo AS. Carrageenans biosynthesized by carposporophytes of red seaweeds Gigartina skottsbergii (Gigartinaceae) and Gymnogongrus torulosus (Phyllophoraceae). J Phycol. 2002;38: 344-58.

17. Nayouf M. Étude rhéologique et structurale de la qualité texturante du sys-tème amidon/kappa-carraghénane en relation avec le traitement thermomécanique (Thèse de Doctorat). Nantes, France: École Nationale des Ingénieurs des Tech-niques des Industries Agricoles et Alimentaires. 2003;198

18. Falshaw R, Bixler HJ, Johndro K. Structure and performance of commercial kappa-2 carrageenan extracts. Pt III. Structure analysis and performance in two dairy applications of extracts from the New Zealand red seaweed. Food Hydrocolloids. 2003;17: 129-39.

19. Cáceres PJ. Carrageenans from chilean samples of Stenogramme interrupta (Phyllophoraceae): structural analysis and biological activity. Phytochemistry. 2000;53: 81-6.

20. Leibbrandt A. Iota-carrageenan is a potent inhibitor of influenza avirus infection. PLoS ONE. 2010;5: 1-12. 
21. De SF-Tischer PC. Chemical structure and antiviral activity of carrageenans from Meristiella gelidium against herpes simplex and dengue virus. Carbohydrate Polymers. 2006;63; 4: 459-65.

22. Wijesekara I, Pangestuti R, Kim SK. Biological activities and potentialhealth benefits of sulfated polysaccharides derived from marine algae. Carbohydrate Polymers. 2011;84(1): 14-21.

23. Yang LQ., Zhang LM. Chemical structural and chain conformational characterization of some bioactive polysaccharides isolated from natural sources. Carbohydrate Polymers. 2009;76(3): 349-61.

24. Yuguchi $Y$, Urakawa $H$, \& Kajiwara K. Structural characteristics ofcarrageenan gels: Various types of counter ions. Food Hydrocolloids. 2003;17: 481-5.

25. Patyukov SD, Okunyeva IA, Zlatova MI. [Influence of different types of dietary fiber on the quality of canned meat.] Scientific works. Odesa National Academy of Food Technologies. 2009;36(2): 94-7. Ukrainian.

26. Stoma M. Food allergies in rural areas Adv. Dermatol. Allergol. 2016;XXXIII(4): 281-5.

27. Webber V. Optimization of extraction of carrageenan Ciênc Tecnol Aliment. 2012;32(4): 812-8.

28. Iglauer S, Wu Y, Shuler P, Tang Y, Goddard WA. Dilute iota- and kappa-Carrageenan solutions with high viscosities in high salinity brines. Journal of Petroleum Science and Engineering. 2011;75: 30411.

29. Naude PJ, Cromarty AD, Van Rensburg CE. Potassium humate inhibits carrageenan-induced paw oedema and a graft-versus-host reaction in rats. Inflammopharmacology. 2010;18: 33-9.

30. Estakhr J, Sanchooli N, Najafi SH., Javdan N. Anti-inflammatory activity of ethanolic extract of Physalis alkekengi Research Journal of Pharmaceutical, Biological and Chemical Sciences. 2011;2: 421-5.

31. Benard C. Degraded carrageenan causing colitis in rats induces TNF secretion and ICAM-1 upregulation in monocytes through NF-kappaB activation. PLoS ONE. 2010;5(1); e8666.

32. Carlucci MJ. Protective effect of a natural carrageenan on genital herpes simplex virus infectionin mice. Antiviral Research. 2004;64: 137-41.

33. Falshaw R, Furneaux RH, Stevenson DE. Structural analysis of carrageenans from the red alga, Callophyllis hombroniana Mont. K (Kallymeniaceae, Rhodophyta). Carbohydr Research. 2005;340(6): 1149-58.

34. De Jesus RMF, de Morais AM, de Morais RM. Marine Polysaccharides from Algae with Potential Biomedical Applications. Marine Drugs. 2015;13(5): 2967-3028.

35. Haijin M, Xiadu J, Huashi G. A k-carrageenan derived oligosaccharide prepared by enzymatic degradation containing anti-tumor activity. Appl Phicol. 2003;15(4): 297303.

36. Cunha L, Grenha A. Sulfated seaweed polysaccharides as multifunctional materials in drug delivery applications. Marine Drugs. 2016;14(3): 42.

37. Chattopadhyay K. Galactan sulfate of Grateloupia indica: Isolation, structural features and antiviral activity. Phytochem. 2007;68(10): 1428-35.

38. Necas J, Bartosikova L. Carrageenan: A review. Vet Med. 2013;58(4): 187-205.

39. Carlucci MJ. Antiherpetic activity and mode of action of natural carrageenans of diverse structural types. Antiviral Res. 1999;43(2): 93-102.

40. Schaeffer DJ., Krylov VS. Anti-HIV activity of extracts and compounds from algae and cyanobacteria. Ecotoxicology and Environmental Safety. 2000;45(3): 208-227.

41. Ghosh T. Focus on antivirally active sulfated polysaccharides: From structure-activity analysis to clinical evaluation Glycobiology. 2009;19(1): 2-15.

42. Kara S, Arda E, Pekcan O. Monovalent and divalent cation effects on phase transitions of $\mathrm{K}$-carrageenan. Journal of Bioactive and Compatible Polymers. 2007;22: 42-61.

43. Bondu S. Carrageenan from Solieria chordalis (Gigartinales): Structural analysis and immunological activities of the low molecular weight fractions. Carbohydr Polym. 2010;81: 2: 448-50.

44. Osmanyan RG. [Prospects for the use of carrageenans in confectionery production (for the production of jelly candies with functional properties)]. Pishchev i pererab promysh. Referat zhurn. 2008;2: 432. Russian.

45. Michon C. Structure evolution of carrageenan/milk gels: effect of shearing, carrageenan concentration and nu fraction on rheological behavior. Food Hydrocolloids. 2005;19(3): 541-7.

46. Thaiudom S, Goff HD. Effect of k-carrageenan on milk protein polysaccharide mixtures. Int Dairy J. 2003;13(9): 763-71.

47. Hamzah HM, Osman A, Tan CP, Mohamad Ghazali F. Carrageenan as an alternative coating for papaya (Carica papaya L. Cv. Eksotika). Postharvest Biology and Technology. 2013;75: 142-6.

48. Yermak IM. Carrageenans-sulfated polysaccharides from red seaweeds as matrices for the inclusion of echinochrome. Mar Drugs. 2017;15(337). Available from: pdfs.semanticscholar.org/a362/ ea5f488b1351b7073ace53 d9327a34916d33.pdf

49. Yuguchi Y, Thu Thuy TT, Urakawa H, Kajiwara K. Structural characteristics of carrageenan gels: Temperature and concentrations dependence. Food Hydrocolloids. 2002;16(6): 515-22. 